\title{
Prognostic and Clinicopathological Value of Cyclin E Expression in Breast Cancer: A Meta-Analysis
}

\author{
Yufei Wang \\ Graduate School of Qinghai University \\ Qijuan Yang \\ Affiliate Hospital of Qnghai University, China \\ Deshou Ma \\ Affiliate Hospital of Qnghai University, China \\ Zhijun Ma \\ Affiliate Hospital of Qnghai University, China \\ Xiaowu Wang ( $\square$ wangxiaowu0516@163.com ) \\ Affiliate Hospital of Qnghai University, China
}

\section{Research Article}

Keywords: Cyclin E, breast cancer, prognosis, system review, meta-analysis

Posted Date: February 22nd, 2021

DOI: https://doi.org/10.21203/rs.3.rs-210720/v1

License: (c) (i) This work is licensed under a Creative Commons Attribution 4.0 International License. Read Full License 


\section{Abstract}

Background: Multiple studies have analyzed the correlation between Cyclin E and breast cancer prognosis, but the results are controversial. In this study, a meta-analysis was used to summarize the published reports, clarify the predictive value of Cyclin E in breast cancer, and the relationship with clinicopathological characteristics.

Methods: A systematic search was retrieved in PubMed, Embase, Web of Science, Cochrane Collaboration Library on the comprehensive search strategy up to 24 August 2020. recurrence-free survival (RFS), overall survival (OS), and breast cancer-specific survival (BCSS) was estimated using pooled hazard ratios (HRs) and risk ratios (RRs) with $95 \%$ confidence intervals (95\% Cls) by univariate and multivariate analysis.

Results: Twenty-eight eligible studies met our inclusion criteria. The present meta-analysis indicates that high cyclin E expression is independently associated with poor OS, BCSS, and RFS in female breast cancer patients by univariate and multivariate analysis. Furthermore, higher histological grades, estrogen receptor (ER)-negativity, positive lymph node metastasis, younger patients, and premenopausal status were associated with Cyclin E overexpression.

Conclusions: High expression of Cyclin E is associated with poor breast cancer outcomes and relevant to multiple clinical characteristics.

\section{Background}

Breast cancer is the most common tumor among women and the leading cause of death. In 2018 , there were about 2.1 million new cases of breast cancer and about 630,000 dead due to breast neoplasms [1]. The key to breast cancer treatment depends mainly on early diagnosis and accurate assessment of prognostic markers that predict the disease development to improve the patient's management.

At present, several independent prognostic factors have been determined, including tumor size, histological grade, lymph node status, hormone receptor status, HER-2 status, and patient age [2-4]. However, most potential prognostic biological markers have not been applied in clinical practice. It is worthy of recognition. Some molecular markers have the possibility of refining the risk assessment.

In the occurrence and progression of breast cancer, the disorder of cell cycle regulation is part of the leading causes of uncontrolled cell proliferation [5]. As a critical regulator of S phase entry, Cyclin E can be bind to and activate Cyclin-dependent kinase-2 (CDK-2) to directly promote G1 to S phase, showing prominent periodic expression in the cell cycle [6, 7]. The over-expression of Cyclin E can accelerate cell entry into the S phase, lead to unlimited cell proliferation, and further cause tumor occurrence and development [8]. Cyclin E is overexpressed in many human tumors, and its genome has been frequently amplified $[9,10]$. Several studies have explored the relationship between Cyclin E and breast cancer patients. However, the prognostic value differs among the studies [11-14]. The reason may be due to the limited sample size, or there may be constant heterogeneity. To assess the influence of Cyclin E expression level on breast cancer and the relationship with clinicopathological characteristics, we performed this meta-analysis to evaluate the prognostic role of Cyclin E or a potential marker as a therapeutic target in breast cancer.

\section{Methods}

The meta-analysis was performed under the Preferred Reporting Items for Systematic Reviews and Meta-analyses (PRISMA) guidance [15]. PubMed, Embase, Cochrane Collaboration Library, and Web of science were searched before 24 August 2020.

\section{Search strategy}

The search strategy included the Mesh terms 'breast cancer' AND 'Cyclin E' AND 'prognosis/survival/prognostic/outcome' with all appropriate subheadings contained. An additional file shows this in more detail [see Additional file 1]. Besides, we manually retrieved references in the included study to identify the need for inclusion in the study.

\section{Inclusion and exclusion criteria}

Inclusion criteria: (1) full-text publication; (2) Studies on the correlation between Cyclin E and prognosis of breast cancer; (3) The subjects were female breast cancer patients diagnosed by pathology; (4) The HR or RR and its $95 \% \mathrm{Cl}$ or its corresponding survival curve were available for data extraction. Exclusion criteria were summarized as follows: (1) Systematic evaluation, meta-analysis, case reports, letters, and comments were excluded; (2) Non-human studies.; (3) The full text of the literature could not be obtained, or the data report was incomplete, or the HR or RR and its $95 \% \mathrm{Cl}$ could not be extracted; (4) Non-English literature.

\section{Data extraction}

The literature selection process is given in Fig. 1. Two independent researchers (Wang YF and Yang QJ) independently screened the literature and extracted the data depending on the inclusion and exclusion criteria. Any differentials in their assessment were resolved by discussion. 
Various contents were extracted, including the first author, number of patients, publication year, age, AJCC stage, histological grade, Detection Method, cut-off value, follow-up period. The Kaplan Meier survival curves were read by Engauge Digitizer version 4.1

(http://digitizer.sourceforge.net/).

\section{Statistical analysis}

In this meta-analysis, HR or RR was used to measure the correlation between Cyclin E and the prognostic factors. Meanwhile, we also analyzed the relationship between Cyclin $\mathrm{E}$ and the clinicopathological characteristics. RR value and $95 \% \mathrm{Cl}$ were used for assessment. Heterogeneity among studying data was evaluated by $\chi^{2}$-based Q-tests and $\mathrm{I}^{2}$ tests. The random-effect model was used only for high heterogeneity $\left(\mathrm{I}^{2}>50 \%\right.$ or $P<0.01$ ); otherwise, fixed-effect model was used [16]. Review Manager, version 5.3 (The Cochrane Collaboration, Copenhagen, Denmark) was used to conduct the meta-analysis. An HR or RR $>1$ indicated a worse outcome for the positive group, and a P-value $<0.05$ throughout was considered statistically significant. Publication bias was assessed by funnel plots $[17,18]$.

\section{Results}

\section{Search results}

A total of 1244 references were retrieved through systematic literature retrieval, of which 476 were duplicated, two were not available, and one was not in English. Through screening the titles and abstracts, 16 studies were non-clinical, 684 articles were unrelated to the study, 27 studies were guides, reviews, letters, or abstracts. After reading the full text, survival data could not be extracted from 9 articles. One article is updated. Finally, 28 studies were included [11-14, 19-42]. The selection flow chart is shown in Fig. 1.

\section{Characteristics of eligible studies}

The included literature was published between 1996 and 2020 and comprised 9289 patients (sample ranged from 56 to 2032 patients) with a median follow-up time ranging from 3 to 15 years. The studies were conducted in 13 countries, with ages ranging between 20 and 90 years (Table 1). Three methods were used to detect Cyclin E level: Western blotting (3 studies), IHC (20 studies), and RT-PCR (5 studies). The different cut-off values and different antibodies were documented by the studies. (Table 2). The prognostic indicators were: overall survival (OS), recurrence-free survival (RFS), and breast cancer-specific survival (BCSS). In our meta-analysis, the results of DFS and MFS were integrated into RFS, and the effect of Cyclin E on prognosis was analyzed from univariate and multivariate situations. (Additional file 2). Recurrence-free survival was defined as time to any type of recurrence or death from any cause. Overall survival was defined from the beginning of the random assignment to death from any cause. Breast cancer-specific survival was defined as time to death from breast cancer. The quality of the eligible literature was assessed using the Newcastle Ottawa Scale (NOS) criteria for cohort studies [43]. The scale evaluates articles from three aspects (selectivity, comparability, and exposure). A score of 7 or more is considered to be of high quality (Additional file 3 ).

Two studies were published on the relation between Cyclin E and breast cancer in 1996 and 1999, respectively [19, 44]. The latter one was an updated article, but they combined cyclin E with other factors when analyzing survival indicators, so we used the former, and only the 100 patients with stage I-III disease were included in the survival analysis. There were two studies [25, 26] based on the same patient cohort. Nevertheless, Kuhling et al.'s paper contained 59 patients who received anti-hormonal therapy, causing the survival data to be different, so both of them were included in the analysis. A similar situation occurred in another three articles [27, 30,31], with varying amounts of sample leading to different data. Potemski et al. wrote two articles in 2009 and 2006 [36, 45], respectively. The paper of 2009 included larger samples from 1997 to 2001, so the 2006 paper was excluded. However, the relationship between Cyclin E and some clinicopathological features was included in this article, so it was used to analyze the relationship between Cyclin $\mathrm{E}$ and clinicopathological characteristics. Since the human genome encodes two E-type cyclins: Cyclin E 1(CCNE1) and Cyclin E 2(CCNE2), CCNE1 is the formerly cyclin E, which is located on chromosome 19q12-q13 (46, 47). Therefore, survival data from three articles $[33,34,41]$ on CCNE1 were included in the study. 
Table 1

Study crowd characteristics

\begin{tabular}{|c|c|c|c|c|c|c|c|c|c|c|}
\hline $\begin{array}{l}\text { First } \\
\text { author, year }\end{array}$ & $\begin{array}{l}\text { No. of } \\
\text { Patients }\end{array}$ & $\begin{array}{l}\text { Median } \\
\text { age } \\
\text { (years) }\end{array}$ & $\begin{array}{l}\text { TNM } \\
\text { Stage }\end{array}$ & $\begin{array}{l}\text { Histological } \\
\text { Grade }\end{array}$ & $\begin{array}{l}\text { Median } \\
\text { Follow-up } \\
\text { (months) }\end{array}$ & Country & $\begin{array}{l}\text { Specimen } \\
\text { collection } \\
\text { time }\end{array}$ & $\begin{array}{l}\text { Adjuvant } \\
\text { therapy }\end{array}$ & Outcomes & NOS \\
\hline $\begin{array}{l}\text { Nielsen et } \\
\text { al. } 1996 \\
\text { [19] }\end{array}$ & 114 & NR & 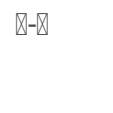 & NR & $\begin{array}{l}53(23- \\
80)\end{array}$ & Sweden & $\begin{array}{l}1988- \\
1991\end{array}$ & $\begin{array}{l}\text { CT, ET, } \\
\text { RT }\end{array}$ & $\begin{array}{l}\text { RFS, } \\
\text { BCSS }\end{array}$ & 8 \\
\hline $\begin{array}{l}\text { Porter et al. } \\
1997 \text { [20] }\end{array}$ & 278 & $20-40$ & NR & intermediate/high & 62.4 & USA & $\begin{array}{l}1983- \\
1992\end{array}$ & NR & OS, BCSS & 7 \\
\hline $\begin{array}{l}\text { Bukholm et } \\
\text { al. } 2001 \\
\text { [21] }\end{array}$ & 170 & $\begin{array}{l}60 \\
(28- \\
88)\end{array}$ & NR & $\nabla-\square$ & $\begin{array}{l}58.8(5- \\
144)\end{array}$ & Norway & $\begin{array}{l}1988- \\
1993\end{array}$ & NR & $\begin{array}{l}\text { BCSS, } \\
\text { RFS }\end{array}$ & 7 \\
\hline $\begin{array}{l}\text { Donnellan } \\
\text { et al. } 2001 \\
\text { [22] }\end{array}$ & 157 & 49 & $\nabla-\nabla$ & $\nabla-\square$ & 36 & $\begin{array}{l}\text { South } \\
\text { Africa }\end{array}$ & $\begin{array}{l}1985- \\
1997\end{array}$ & $\begin{array}{l}\text { CT, ET, } \\
\text { RT }\end{array}$ & OS & 8 \\
\hline $\begin{array}{l}\text { Kim et al. } \\
2001 \text { [23] }\end{array}$ & 128 & NR & $\nabla-\rrbracket$ & $\nabla-\square$ & $\begin{array}{l}69.6(3.3- \\
121.5)\end{array}$ & Korea & $\begin{array}{l}1989- \\
1992\end{array}$ & $\begin{array}{l}\text { CT, ET, } \\
\text { RT }\end{array}$ & OS, RFS & 8 \\
\hline $\begin{array}{l}\text { Keyomarsi } \\
\text { et al. } 2002 \\
\text { [11] }\end{array}$ & 395 & 64 & $\nabla-\nabla$ & NR & 76.8 & USA & $\begin{array}{l}1990- \\
1995\end{array}$ & NR & BCSS, OS & 7 \\
\hline $\begin{array}{l}\text { Han et al. } \\
2003 \text { [24] }\end{array}$ & 175 & NR & $\mathrm{Q}-\mathrm{Q} \mathrm{Q}$ & $\nabla-\square$ & $\begin{array}{l}75(2- \\
169)\end{array}$ & Korea & $\begin{array}{l}1994- \\
1997\end{array}$ & CT, ET & OS & 7 \\
\hline $\begin{array}{l}\text { Kühling, H } \\
\text { et al. } 2003 \\
\text { [25] }\end{array}$ & 332 & $\begin{array}{l}61 \\
(23- \\
91)\end{array}$ & $\Delta-\Delta \nabla$ & NR & $\begin{array}{l}99(24- \\
208)\end{array}$ & Sweden & $\begin{array}{l}1970- \\
1986\end{array}$ & NR & $\begin{array}{l}\text { BCSS, } \\
\text { RFS }\end{array}$ & 8 \\
\hline $\begin{array}{l}\text { Rudolph et } \\
\text { al. } 2003 \\
{[26]}\end{array}$ & 273 & $\begin{array}{l}61 \\
(23- \\
91)\end{array}$ & 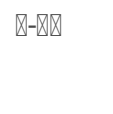 & NR & $\begin{array}{l}99(24- \\
208)\end{array}$ & Sweden & $\begin{array}{l}1970- \\
1986\end{array}$ & NR & BCSS & 7 \\
\hline $\begin{array}{l}\text { Span et al. } \\
2003 \text { [13] }\end{array}$ & 277 & $\begin{array}{l}60 \\
(31- \\
88)\end{array}$ & $1-\otimes$ & $1-\nabla$ & $75(2-169)$ & Netherlands & $\begin{array}{l}1987- \\
1997\end{array}$ & $\begin{array}{l}\text { CT, ET, } \\
\text { RT }\end{array}$ & OS, RFS & 7 \\
\hline $\begin{array}{l}\text { Foulkes et } \\
\text { al. } 2004 \\
\text { [27] }\end{array}$ & 241 & 65 & NR & NR & 95 & Canada & $\begin{array}{l}1980- \\
1995\end{array}$ & NR & BCSS & 7 \\
\hline $\begin{array}{l}\text { Lindahl et } \\
\text { al. 2004 } \\
\text { [28] }\end{array}$ & 270 & 63 & NR & $1-\nabla$ & 122 & Sweden & $\begin{array}{l}1987- \\
1999\end{array}$ & CT, ET & os & 7 \\
\hline $\begin{array}{l}\text { Peters et al. } \\
2004 \text { [29] }\end{array}$ & 56 & NR & $\nabla-\nabla \otimes$ & $1-\nabla$ & NR & Argentina & $\begin{array}{l}1995- \\
1999\end{array}$ & $\mathrm{CT}, \mathrm{RT}$ & RFS & 7 \\
\hline $\begin{array}{l}\text { Arnes et al. } \\
2005 \text { [30] }\end{array}$ & 259 & 65 & NR & $1-\nabla$ & 117.6 & Canada & $\begin{array}{l}1980- \\
1995\end{array}$ & NR & BCSS & 8 \\
\hline $\begin{array}{l}\text { Chappuis } \\
\text { et al. } 2005 \\
\text { [31] }\end{array}$ & 278 & 65 & NR & NR & 96 & Canada & $\begin{array}{l}1980- \\
1995\end{array}$ & $\mathrm{CT}, \mathrm{RT}$ & BCSS & 8 \\
\hline $\begin{array}{l}\text { Brennan et } \\
\text { al. 2006 } \\
\text { [12] }\end{array}$ & 400 & 50 & 0 & NR & 166.8 & Sweden & $\begin{array}{l}1984- \\
1991\end{array}$ & $\mathrm{CT}, \mathrm{RT}$ & BCSS & 8 \\
\hline $\begin{array}{l}\text { Callagy et } \\
\text { al. 2006 } \\
\text { [32] }\end{array}$ & 651 & $\begin{array}{l}48.5 \\
(22- \\
90)\end{array}$ & $1-\otimes$ & NR & $\begin{array}{l}104.4 \\
\left(4.8^{-}\right. \\
472.8)\end{array}$ & British & $\begin{array}{l}1970- \\
1990\end{array}$ & NR & os & 7 \\
\hline $\begin{array}{l}\text { Desmedt et } \\
\text { al. } 2006 \\
\text { [33] }\end{array}$ & 205 & 50 & $1-\otimes$ & $1-\nabla$ & 97.3 & British & NR & NR & RFS & 7 \\
\hline $\begin{array}{l}\text { Porter et al. } \\
2006 \text { [14] }\end{array}$ & 2032 & $\begin{array}{l}47 \\
(21- \\
76)\end{array}$ & $1-\otimes$ & NR & 84 & USA & $\begin{array}{l}1994- \\
1997\end{array}$ & CT & OS, RFS & 7 \\
\hline
\end{tabular}




\begin{tabular}{|c|c|c|c|c|c|c|c|c|c|c|}
\hline $\begin{array}{l}\text { First } \\
\text { author, year }\end{array}$ & $\begin{array}{l}\text { No. of } \\
\text { Patients }\end{array}$ & $\begin{array}{l}\text { Median } \\
\text { age } \\
\text { (years) }\end{array}$ & $\begin{array}{l}\text { TNM } \\
\text { Stage }\end{array}$ & $\begin{array}{l}\text { Histological } \\
\text { Grade }\end{array}$ & $\begin{array}{l}\text { Median } \\
\text { Follow-up } \\
\text { (months) }\end{array}$ & Country & $\begin{array}{l}\text { Specimen } \\
\text { collection } \\
\text { time }\end{array}$ & $\begin{array}{l}\text { Adjuvant } \\
\text { therapy }\end{array}$ & Outcomes & NOS \\
\hline $\begin{array}{l}\text { Sieuwertset } \\
\text { al. 2006 } \\
\text { [34] }\end{array}$ & 635 & $\begin{array}{l}56 \\
(25- \\
88)\end{array}$ & $1-\nabla$ & NR & $\begin{array}{l}95(11- \\
202)\end{array}$ & Netherlands & $\begin{array}{l}1979- \\
1995\end{array}$ & $\begin{array}{l}\mathrm{CT}, \mathrm{ET} \text {, or } \\
\mathrm{RT}\end{array}$ & OS,RFS & 8 \\
\hline $\begin{array}{l}\text { Somlo et } \\
\text { al.2008 } \\
\text { [35] }\end{array}$ & 239 & $\begin{array}{l}46 \\
(26- \\
62)\end{array}$ & II- & NR & $\begin{array}{l}86(20- \\
155)\end{array}$ & USA & $\begin{array}{l}1989- \\
2001\end{array}$ & $\begin{array}{l}\text { CT, ET, } \\
\text { RT }\end{array}$ & OS,RFS & 8 \\
\hline $\begin{array}{l}\text { Potemski } \\
\text { et al. } 2009 \\
\text { [36] }\end{array}$ & 174 & 50 & $\mathrm{I}-\mathbb{\nabla}$ & NR & $\begin{array}{l}58(1- \\
78)\end{array}$ & Poland & $\begin{array}{l}1997- \\
2001\end{array}$ & $\begin{array}{l}\text { CT, RT, } \\
\text { ET }\end{array}$ & BCSS & 8 \\
\hline $\begin{array}{l}\text { Sgambato } \\
\text { et al. } 2009 \\
\text { [37] }\end{array}$ & 134 & $\begin{array}{l}56 \\
(32- \\
77)\end{array}$ & $1-\nabla$ & NR & $\begin{array}{l}72(21- \\
122)\end{array}$ & Italy & $\begin{array}{l}1994- \\
2001\end{array}$ & $\mathrm{CT}, \mathrm{RT}$ & os & 7 \\
\hline $\begin{array}{l}\text { Lemée et } \\
\text { al. 2010 } \\
\text { [38] }\end{array}$ & 206 & $18-64$ & $1-\otimes$ & NR & 60 & French & $\begin{array}{l}1997- \\
2000\end{array}$ & NR & os & 7 \\
\hline $\begin{array}{l}\text { Tokai et al. } \\
2011 \text { [39] }\end{array}$ & 69 & $\begin{array}{l}55.6 \\
(34- \\
87)\end{array}$ & $1-\nabla$ & NR & 60 & Japan & $\begin{array}{l}2000- \\
2004\end{array}$ & NR & OS, RFS & 7 \\
\hline $\begin{array}{l}\text { Voduc et } \\
\text { al. } 2008 \\
{[40]}\end{array}$ & 438 & 60 & $1-\nabla$ & NR & 180 & Canada & $\begin{array}{l}1974- \\
1995\end{array}$ & NR & BCSS & 8 \\
\hline $\begin{array}{l}\text { Lundgren } \\
\text { et al. } 2015 \\
\text { [41] }\end{array}$ & 186 & 66 & $1-\nabla$ & $1-\nabla$ & NR & Sweden & $\begin{array}{l}1993- \\
2004\end{array}$ & NR & BCSS & 7 \\
\hline $\begin{array}{l}\text { Johnston } \\
\text { et al. } 2020 \\
\text { [42] }\end{array}$ & 517 & $\geq 70$ & $\mathrm{H}-\mathrm{I}$ & NR & $\begin{array}{l}75.6 \\
(73.2- \\
80.4)\end{array}$ & British & $\begin{array}{l}1973- \\
2010\end{array}$ & NR & OS, BCSS & 8 \\
\hline
\end{tabular}


Table 2

Technical details of the method for Cyclin E quantification

\begin{tabular}{|c|c|c|c|c|}
\hline First author, year & Detection method & Cut off & Antibody & Prevalence (high/total) \\
\hline Nielsen et al. 1996 [19] & WB & $\geq 0.5$ & NR & $27 \% \Delta / 29.8 \%$ \\
\hline Porter et al. 1997 [20] & $\mathrm{IHC}$ & >benign breast epithelium & affinity-purified anti-Cyclin E & $35 \%$ \\
\hline Bukholm et al. 2001 [21] & $\mathrm{IHC}$ & $>30 \%$ & NR & $21.8 \%(37 / 170)$ \\
\hline Donnellan et al. 2001 [22] & $\mathrm{IHC}$ & $>5 \%$ & $\begin{array}{l}\text { IgG2a kappa mouse } \\
\text { monocloNRI Cyclin E antibody }\end{array}$ & $46.2 \%(72 / 156)$ \\
\hline Kim et al. 2001 [23] & $\mathrm{IHC}$ & $>50 \%$ & rabbit polycloNRI anti-Cyclin E & $40.6 \%(52 / 128)$ \\
\hline $\begin{array}{l}\text { Keyomarsi et al. } 2002 \\
\text { [11] }\end{array}$ & WB & >benign breast epithelium & monoclonal antibody HE12 & $32 \%(125 / 395)$ \\
\hline Han et al. 2003 [24] & $\mathrm{IHC}$ & $>10 \%$ & rabbit polycloNRI IgG anti-Cyclin E & $27.4 \%(48 / 175)$ \\
\hline Kühling, $\mathrm{H}$ et al. 2003 [25] & $\mathrm{IHC}$ & $>10 \%$ & NR & NR \\
\hline Rudolph et al. 2003 [26] & $\mathrm{IHC}$ & $>10 \%$ & NR & NR \\
\hline Span et al. 2003 [13] & RT-PCR & NR & NR & $28 \%(78 / 277)$ \\
\hline Foulkes et al. 2004 [27] & $\mathrm{IHC}$ & >benign breast epithelium & affınity-purified anti-Cyclin E & $26 \%(63 / 241)$ \\
\hline Lindahl et al. 2004 [28] & $\mathrm{IHC}$ & $\geq 50 \%$ & mouse monoclonal anti-Cyclin $\mathrm{E}$ & $10 \%(27 / 270)$ \\
\hline Peters et al. 2004 [29] & $\mathrm{IHC}$ & $>10 \%$ & HE12, cat no. sc-247 & $58.9 \%(33 / 56)$ \\
\hline Arnes et al. 2005 [30] & $\mathrm{IHC}$ & NR & affinity-purified anti-Cyclin E & NR \\
\hline Chappuis et al. 2005 [31] & $\mathrm{IHC}$ & >benign breast epithelium & affinity-purified anti-Cyclin E & $26.5 \%(67 / 253)$ \\
\hline Brennan et al. 2006 [12] & $\mathrm{IHC}$ & $>25 \%$ & NR & NR \\
\hline Callagy et al. 2006 [32] & $\mathrm{IHC}$ & $>25 \%$ & NR & NR \\
\hline Desmedt et al. 2006 [33] & RT-PCR & NR & NR & NR \\
\hline Porter et al. 2006 [14] & $\mathrm{IHC}$ & high scores:4-7 & anti-Cyclin E polyclonal antibody & NR \\
\hline Sieuwertset al. 2006 [34] & RT-PCR & 0.03 & NR & $60.5 \%(384 / 635)$ \\
\hline Somlo et al. 2008 [35] & RT-PCR & $>0.9$ & NR & $25.2 \%(31 / 123)$ \\
\hline Potemski et al. 2009 [36] & $\mathrm{IHC}$ & $\geq 2 \%$ & anti-Cyclin E monoclonal antibody & $56.9 \%(99 / 174)$ \\
\hline Sgambato et al. 2009 [37] & $\mathrm{IHC}$ & $>11 \%$ & NR & $34.3 \%(46 / 134)$ \\
\hline Lemée et al. 2010 [38] & RT-PCR & $>0.182$ & NR & NR \\
\hline Tokai et al. 2011 [39] & WB & NR & NR & $65.2 \%(45 / 69)$ \\
\hline Voduc et al. 2008 [40] & $\mathrm{IHC}$ & $>10 \%$ & mouse monoclonal anti-Cyclin E & $46 \%(146 / 319)$ \\
\hline Lundgren et al. 2015 [41] & $\mathrm{IHC}$ & $>20 \%$ & anti-Cyclin E monoclonal antibody & NA \\
\hline Johnston et al. 2020 [42] & $\mathrm{IHC}$ & $>5 \%$ & $\begin{array}{l}\text { mouse monoclonal antibodies } \\
\text { and rabbit polyclonal antibodies }\end{array}$ & $38.6 \%(199 / 516)$ \\
\hline
\end{tabular}


Table 3

Correlation between high Cyclin E level and clinicopathological parameters

\begin{tabular}{|c|c|c|c|c|c|c|c|}
\hline Outcome & boundary & Studies & Patients & Heterogeneity & Model & $\mathrm{RR}$ [95\% Cl] & P-value \\
\hline Age & $\nabla 50$ years; $\geq 50$ years & 4 & & $P=0.03 ; I^{2}=66 \%$ & REM & $1.56[1.03,2.34]$ & 0.03 \\
\hline Tumor size & $\otimes 20 \mathrm{~mm} ; \geq 20 \mathrm{~mm}$ & 9 & & $P=0.02 ; I^{2}=56 \%$ & REM & $0.86[0.70,1.05]$ & 0.14 \\
\hline ER status & $+/-$ & 10 & & $P<0.0001 ;\left.\right|^{2}=90 \%$ & REM & $0.56[0.38,0.84]$ & 0.005 \\
\hline PR status & $+/-$ & 4 & & $P<0.0001 ; I^{2}=91 \%$ & REM & $0.80[0.45,1.44]$ & 0.46 \\
\hline Disease stage & $\nabla / \nabla$ & 5 & & $P=0.98 ; I^{2}=0 \%$ & FEM & $0.83[0.67,1.01]$ & 0.07 \\
\hline Histological type & Ductal/Lobular & 2 & & $P=0.20 ; I^{2}=39 \%$ & FEM & $1.39[0.75,2.56]$ & 0.30 \\
\hline Histological grade & $\nabla / \nabla$ & 6 & & $P<0.0001 ;\left.\right|^{2}=87 \%$ & REM & $0.41[0.17,0.99]$ & 0.05 \\
\hline lymph node status & $+/-$ & 8 & & $P=0.08 ; 1^{2}=44 \%$ & FEM & $1.29[1.11,1.50]$ & 0.0009 \\
\hline Menopausal status & Pre/Post & 3 & & $P=0.16 ; I^{2}=46 \%$ & FEM & $1.58[1.11,2.23]$ & 0.01 \\
\hline HER2 status & $+/-$ & 3 & & $P=0.68 ; I^{2}=0 \%$ & FEM & $1.11[0.92,1.33]$ & 0.27 \\
\hline Nuclear stage & $\nabla / \nabla$ & 2 & & $P=0.12 ; I^{2}=59 \%$ & REM & $1.03[0.51,2.07]$ & 0.93 \\
\hline
\end{tabular}

\section{Outcomes}

\section{Impact of cyclin E level on BCSS}

A total of 13 articles assessed the relationship between Cyclin E and BCSS in breast cancer patients. The result suggested that high Cyclin E expression was a prognostic indicator of poor BCSS both in univariate and multivariate analysis using $\mathrm{RR}(2.06,95 \% \mathrm{Cl}, 1.48-2.87$, $\mathrm{P}<0.0001$; $2.52,95 \% \mathrm{Cl}, 1.70-3.74, \mathrm{p}<0.00001$ ) as shown in Fig. 2C and 2D. When HR was used, high Cyclin E overexpression was only statistically significantly associated with poor BCSS in univariate analysis. The combined HR for BCSS was 2.62, with a $95 \% \mathrm{Cl} 1.26-5.42$ ( $p=0.01)$, as shown in Fig. 2A. The multivariate analysis results were close to statistical significance ( $\mathrm{HR}, 2.08,95 \% \mathrm{Cl}, 0.91-4.78, \mathrm{P}=0.08)$, as shown in Fig. 2B. Heterogeneity was high for the results. Thus, a random-effects model was used.

\section{Impact of cyclin E level on OS}

Fifteen articles analyzed the relationship between Cyclin E and OS. High Cyclin E expression served as a marker of reduced overall survival in all patients. In univariate analysis, worse OS (HR 1.85, 95\% Cl 1.31-2.59; P<0.0004; RR 1.93, 95\% Cl 1.32-2.81; P = 0.0006) were observed among patients considered as Cyclin E positive (Fig. $3 \mathrm{~A}$ and $3 \mathrm{C}$ ) therefore the random-effect model was used for significant heterogeneity $\left(\mathrm{P}=0.003, \mathrm{I}^{2}\right.$ $=67 \% ; \mathrm{P}=0.03, \mathrm{I}^{2}=63 \%$ ). For the multivariate analysis, worse OS was found in the breast cancer patients with Cyclin $\mathrm{E}$ overexpression (HR 2.36 , $95 \% \mathrm{Cl} 1.78-3.12 ; \mathrm{P}<0.00001 ; \mathrm{RR} 3.10,95 \% \mathrm{Cl} 2.08-4.63 ; \mathrm{P}<0.00001)$ as shown in Fig. 3B and 3D. Since there was no heterogeneity $(\mathrm{P}=0.88$, $\left.I^{2}=0 \% ; P=0.48, I^{2}=0 \%\right)$, a fixed-effect model was applied.

\section{Impact of cyclin E level on RFS}

The pooled HR for recurrence-free survival (RFS) was reported in seven studies. We found that worse RFS (HR 1.88, 95\% Cl 1.15-3.07; $p=0.01$ ) was observed among patients considered Cyclin E positive in univariate analysis (Fig. 4A), since the random-effects model was used for significant heterogeneity $\left(\mathrm{P}<0.00001, \mathrm{I}^{2}=87 \%\right)$. While, high cyclin $\mathrm{E}$ expression levels showed significant association with poor RFS (RR 1.98 , $95 \% \mathrm{Cl} 1.28-3.08 ; \mathrm{p}=0.002)$ in the multivariate analysis while not significant in a univariate model $(\mathrm{RR} 2.56,95 \% \mathrm{Cl} 0.89-7.43, \mathrm{p}=0.08)(\mathrm{Fig} .4 \mathrm{~B}$, 4C).

\section{Relationship between Cyclin E and clinicopathological features}

We also investigated the relationship between Cyclin $\mathrm{E}$ and clinicopathological characteristics. The pooled results showed that Cyclin $\mathrm{E}$ expression was increased in patients with young age $(R R=1.56,95 \% \mathrm{Cl}, 1.03-2.34 ; \mathrm{P}=0.03)$, estrogen receptor $(\mathrm{ER})$-negativity $(\mathrm{RR}=1.77,95 \%$ $\mathrm{Cl}, 1.19-2.64 ; \mathrm{P}=0.005)$, premenopausal status $(\mathrm{RR}=1.58,95 \% \mathrm{Cl} 1.11-2.23 ; \mathrm{P}=0.01)$ and lymph node-positivity $(\mathrm{RR}=1.29,95 \% \mathrm{Cl}, 1.11-1.50$; $\mathrm{P}=0.0009)$. High histological grade was a borderline significance $(R R=2.46,95 \% \mathrm{Cl}, 1.01-5.96 ; \mathrm{P}=0.05)$. However, other clinicopathological 
factors were not correlated with Cyclin E overexpression, including tumor size, PR status, disease stage, histological type, HER2 status, and nuclear stage (Table 3), the forest plots were shown in Additional file 4.

Any deletion of the literature in this study will not affect the results of this study, which means that the calculation results of the above random effect are stable and reliable. In the subgroup studies with more than five included literature, funnel plots were used to evaluate publication bias

(Fig. 5). As can be seen from the figures, funnel plots of each study were basically symmetrical, so it can be judged that there was no publication bias in this study.

\section{Discussion}

Breast cancer is a complex process involving multiple factors, one of the most critical aspects is the disorder of cell cycle regulation [5]. Accurate prediction of prognosis is one of the most critical problems in breast cancer treatment. The prediction of breast cancer is closely related to the disease stage, and early diagnosis of the disease is crucial to the patient's prognosis. Once the risk of recurrence has been determined, it can be used to evaluate the potential effects of endocrine therapy, chemotherapy, or a combination of these treatments. The determination of accurate prognostic indicators will also influence the patient's individualized treatment. Also, identifying prognostic factors with potential biological significance can be used as therapeutic targets, which will be of great relevance to identifying and treating high-risk patients. The cell cycle is divided into several stages artificially, including G0/G1, S, G2, and M phase. Cyclins play different roles at different cell cycle stages depending on their sequence primitives, expression, and activation forms [48]. Cyclins, along with the cyclin-dependent kinase (CDKs) and cyclin-dependent kinase inhibitors (CKIs), constitute the cycle regulation system to ensure the cell cycle orderly [49]. The limitation point of transition from the G1 to the $\mathrm{S} 1$ phase is crucial for cell proliferation and differentiation [50]. The primary function of Cyclin $\mathrm{E}$ is to regulate the restriction point "R" at the end of the G1-phase to allow cells to enter the S phase [51, 52]. The restriction point "R" was found to be the endpoint in the transition of the G1 to $S$ phase of the cell cycle, which plays a crucial role in cell regulation and prevents the excessive and unrestricted proliferation of cells. It was found that overexpression of Cyclin E could accelerate the G1 phase of the cell cycle [53]. The destruction of these pathways or the absence or overexpression of specific factors is closely related to the malignant transformation of cells and cancer development [54]. Cyclin E expression levels are elevated significantly in many human tumors, manifested by amplification of the genome locus at which it is located (19q12-Q13) [55, 56], leading to widespread concern about its role in tumors. The over-expressed Cyclin E manifests as different molecular phenotypes in breast cancer and issue in the inactivation of the pRb pathway. A lower molecule form of Cyclin E derived from calpain induces a higher kinase activity $[57,58]$. It has been pointed out that the oncogenic activity of Cyclin E can be inhibited by truncating the protein [59]. At present, many studies have assessed that the overexpression of Cyclin E may be a prognostic factor of breast cancer patients. Most of the research shows that Cyclin $\mathrm{E}$ can indicate breast cancer prognosis, but other studies could not confirm this finding. The present meta-analysis is an updated one to investigate the correlation between Cyclin E expression and breast cancer prognosis.

In this study, a quantitative and systematic analysis was conducted on the published literature. Through reasonable inclusion and exclusion criteria, available literature was obtained, and relevant data were extracted. The correlation between the high expression of Cyclin E in breast cancer and prognosis and clinicopathological characteristics were analyzed systematically.

As the data are shown above, our meta-analysis results demonstrate that Cyclin E overexpression was statistically significantly associated with worse OS, BCSS, and RFS either in univariate or multivariate analysis in the overall population. In contrast to the previous two meta-analyses [60, 61]. Our results suggest that Cyclin E overexpression is associated with poor RFS, which is different from previous studies.

In the original studies, the authors used hazard ratios and risk ratios to analyze the association between Cyclin $\mathrm{E}$ and prognosis in breast cancer patients using univariate and multivariate analyses. RR is a measure of the strength of the association between exposure and outcome, that is, the ratio of morbidity or mortality in the exposed group to that in the non-exposed group, and applies to cohort studies or randomized controlled trials. RR indicates how many times the risk of morbidity or death in the exposed group is that of the non-exposed group. The more significant the RR value, the greater the effect of exposure, the stronger the association between exposure and outcome. The hazard ratio (HR), which is the ratio of the risk function of the exposed group to the non-exposed group, is generally obtained from the Cox proportional risk model. Most people think that HR and RR mean the same thing, but HR has a time factor. In other words, RR with time effect is HR. In the survival data, RR takes into account the difference in endpoint events, while HR takes into account the presence of endpoint events and the time taken to reach the endpoint. Therefore, there are differences between the two, and it is necessary to analyze them separately. Besides, in some literature, Cyclin E was a statistically significant prognostic indicator in univariate analysis, but not in multivariate analysis, so we also analyzed it from two aspects. Meanwhile, we also analyzed the relationship between Cyclin E and different clinical characteristics. Cyclin E overexpression was significantly correlated with age, ER status, menopausal status, and lymph node metastasis, but not with tumor size, PR status, disease stage, histological type, HER2 status, and nuclear grade.

Several limitations are present in this meta-analysis. First, cyclin E positivity was evaluated using different methods, antibodies, scoring methods, and high Cyclin E is defined according to the cut-off chosen by each author. Therefore, heterogeneities exist in cut-offs of a high level of cyclin E. Keyomarsi K et al. [62] reported that tumor cells often overexpress low-molecular-weight (LMW) cyclin E forms, which was obtained 
by cleaving Cyclin E with elastase [63]. LMW has a high prognostic value in primary breast cancer [13, 22, 24]. However, some immunohistochemical assays lack antibodies to detect the amino terminus that may lead to the differences in the prognostic value of Cyclin E in previous studies. Second, the differences in selected patients, adjuvant therapy resulted in bias in the analysis. Moreover, all samples in the studies were obtained through modified radical mastectomy or breast-conserving surgery, and most of the studies clearly stated that no preoperative anti-tumor therapy had been given. Meanwhile, some articles did not mention preoperative treatment, which may affect the detection of Cyclin E. Therefore, the combined results should be interpreted with caution.

\section{Conclusion}

In conclusion, our results suggest that high expression of Cyclin E may be a prognostic marker for poor OS, BCSS, and RFS regardless of age, HR status, and axillary lymph node status. Cyclin E overexpression was significantly associated with a range of clinicopathological parameters, such as age, lymph node metastasis, ER-negative and menopausal status. This information may help clinicians screen patients for anti-cyclin $\mathrm{E}$ therapy. To determine the role of Cyclin E expression in breast cancer, high-quality studies in more extensive, homogeneous populations are needed.

\section{Abbreviations}

CT

chemotherapy; ET:endocrine therapy; RT:radiotherapy; HR:hazard ratio; RR:risk ratio; Cl:Confidence interval; RFS, recurrence-free survival; OS, overall survival. BCSS:breast cancer-specific survival; WB:Western blot; IHC, immunohistochemistry; RT-PCR:reverse transcription-polymerase chain reaction; HER2:Human epidermal growth factor receptor-2; NR:not reported.

\section{Declarations}

\section{Ethics approval and consent to participate}

Not applicable

\section{Consent for publication}

Not Applicable.

\section{Availability of data and materials}

The datasets used and analyzed during the current study are available from the corresponding author on reasonable request.

\section{Conflict of interest}

The authors declare that they have no competing interests.

\section{Funding}

This work was supported by grants from the National Natural Science Foundation of China (82060485) and the Foundation of Science and Technology Department of Qinghai Province (NO. 2019-ZJ-7091).

\section{Authors' contributions}

WYF and MZJ designed the study. WYF and YQJ searched the literature and collected data, analyzed and drafted the manuscript. MZJ, WXW, and MDS reviewed and revised the manuscript. All authors read and approved the final manuscript.

\section{Acknowledgments}

Not applicable.

\section{Author Details}

*Corresponding Author: wangxiaowu0516@163.com. 1Graduate School of Qinghai University, 810016, No. 251, Ningda road, Xining, Qinghai, China. ${ }^{2}$ Teaching Management Department, The Affiliated Hospital of Qinghai University, 810001, No. 29, Tongren Road, Xining, Qinghai, China. ${ }^{3}$ Department of Surgery of Breast and Thyroid Oncology, The Affiliated Hospital of Qinghai University, 810001, No. 29, Tongren Road, Xining, Qinghai, China. 


\section{References}

1. Bray F, Ferlay J, Soerjomataram I, Siegel RL, Torre LA, Jemal A. Global cancer statistics 2018: GLOBOCAN estimates of incidence and mortality worldwide for 36 cancers in 185 countries. CA Cancer J Clin. 2018 Nov;68(6):394-424.

2. Colozza M, Azambuja E, Cardoso F, Sotiriou C, Larsimont D, Piccart MJ. Proliferative markers as prognostic and predictive tools in early breast cancer: where are we now? Ann Oncol. 2005 Nov;16(11):1723-39.

3. Hayes DF. Prognostic and predictive factors revisited. Breast. 2005 Dec;14(6):493-9.

4. Callagy GM, Webber MJ, Pharoah PD, Caldas C. Meta-analysis confirms BCL2 is an independent prognostic marker in breast cancer. BMC Cancer. 2008 May 29;8:153.

5. Sherr CJ. Cancer cell cycles. Science. 1996 Dec 6;274(5293):1672-7.

6. Dulić V, Lees E, Reed SI. Association of human cyclin E with a periodic G1-S phase protein kinase. Science. 1992 Sep 25;257(5078):195861.

7. Koff A, Cross F, Fisher A, Schumacher J, Leguellec K, Philippe M, Roberts JM. Human cyclin E, a new cyclin that interacts with two members of the CDC2 gene family. Cell. 1991 Sep 20;66(6):1217-28.

8. Keyomarsi K, Herliczek TW. The role of cyclin E in cell proliferation, development and cancer. Prog Cell Cycle Res. 1997;3:171-91.

9. Akama Y, Yasui W, Yokozaki H, Kuniyasu H, Kitahara K, Ishikawa T, Tahara E. Frequent amplification of the cyclin E gene in human gastric carcinomas. Jpn J Cancer Res. 1995 Jul;86(7):617-21.

10. Demetrick DJ, Matsumoto S, Hannon GJ, Okamoto K, Xiong Y, Zhang H, Beach DH. Chromosomal mapping of the genes for the human cell cycle proteins cyclin C (CCNC), cyclin E (CCNE), p21 (CDKN1) and KAP (CDKN3). Cytogenet Cell Genet. 1995;69(3-4):190-2.

11. Keyomarsi K, Tucker SL, Buchholz TA, Callister M, Ding Y, Hortobagyi GN, Bedrosian I, Knickerbocker C, Toyofuku W, Lowe M, Herliczek TW, Bacus SS. Cyclin E and survival in patients with breast cancer. N Engl J Med. 2002 Nov 14;347(20):1566-75.

12. Brennan DJ, Jirstrom K, Kronblad A, Millikan RC, Landberg G, Duffy MJ, Rydén L, Gallagher WM, O'Brien SL. CA IX is an independent prognostic marker in premenopausal breast cancer patients with one to three positive lymph nodes and a putative marker of radiation resistance. Clin Cancer Res. 2006 Nov 1;12(21):6421-31.

13. Span PN, Tjan-Heijnen VC, Manders P, Beex LV, Sweep CG. Cyclin-E is a strong predictor of endocrine therapy failure in human breast cancer. Oncogene. 2003 Jul 31;22(31):4898-904.

14. Porter PL, Barlow WE, Yeh IT, Lin MG, Yuan XP, Donato E, Sledge GW, Shapiro CL, Ingle JN, Haskell CM, Albain KS, Roberts JM, Livingston RB, Hayes DF. p27(Kip1) and cyclin E expression and breast cancer survival after treatment with adjuvant chemotherapy. J Natl Cancer Inst. 2006 Dec 6;98(23):1723-31.

15. Moher D, Liberati A, Tetzlaff J, Altman DG; PRISMA Group. Preferred reporting items for systematic reviews and meta-analyses: the PRISMA statement. Int J Surg. 2010;8(5):336-41.

16. Higgins JP, Thompson SG, Deeks JJ, Altman DG. Measuring inconsistency in meta-analyses. BMJ. 2003 Sep 6;327(7414):557-60.

17. Begg CB, Mazumdar M. Operating characteristics of a rank correlation test for publication bias. Biometrics. 1994 Dec;50(4):1088-101.

18. Egger M, Davey Smith G, Schneider M, Minder C. Bias in meta-analysis detected by a simple, graphical test. BMJ. 1997 Sep 13;315(7109):629-34.

19. Nielsen NH, Arnerlöv C, Emdin SO, Landberg G. Cyclin E overexpression, a negative prognostic factor in breast cancer with strong correlation to oestrogen receptor status. $\mathrm{Br} \mathrm{J}$ Cancer. $1996 \mathrm{Sep} ; 74(6): 874-80$.

20. Porter PL, Malone KE, Heagerty PJ, Alexander GM, Gatti LA, Firpo EJ, Daling JR, Roberts JM. Expression of cell-cycle regulators p27Kip1 and cyclin $\mathrm{E}$, alone and in combination, correlate with survival in young breast cancer patients. Nat Med. 1997 Feb;3(2):222-5.

21. Bukholm IR, Bukholm G, Nesland JM. Over-expression of cyclin A is highly associated with early relapse and reduced survival in patients with primary breast carcinomas. Int J Cancer. $2001 \mathrm{Jul}$ 15;93(2):283-7.

22. Donnellan R, Kleinschmidt I, Chetty R. Cyclin E immunoexpression in breast ductal carcinoma: pathologic correlations and prognostic implications. Hum Pathol. 2001 Jan;32(1):89-94.

23. Kim HK, Park IA, Heo DS, Noh DY, Choe KJ, Bang YJ, Kim NK. Cyclin E overexpression as an independent risk factor of visceral relapse in breast cancer. Eur J Surg Oncol. 2001 Aug;27(5):464-71.

24. Han S, Park K, Bae BN, Kim KH, Kim HJ, Kim YD, Kim HY. Prognostic implication of cyclin E expression and its relationship with cyclin D1 and p27Kip1 expression on tissue microarrays of node negative breast cancer. J Surg Oncol. 2003 Aug;83(4):241-7.

25. Kühling H, Alm P, Olsson H, Fernö M, Baldetorp B, Parwaresch R, Rudolph P. Expression of cyclins $E$, A, and B, and prognosis in lymph nodenegative breast cancer. J Pathol. 2003 Apr;199(4):424-31.

26. Rudolph P, Kühling H, Alm P, Fernö M, Baldetorp B, Olsson H, Parwaresch R. Differential prognostic impact of the cyclins E and B in premenopausal and postmenopausal women with lymph node-negative breast cancer. Int J Cancer. 2003 Jul 10;105(5):674-80.

Page $10 / 17$ 
27. Foulkes WD, Brunet JS, Stefansson IM, Straume O, Chappuis PO, Bégin LR, Hamel N, Goffin JR, Wong N, Trudel M, Kapusta L, Porter P, Akslen LA. The prognostic implication of the basal-like (cyclin E high/p27 low/p53+/glomeruloid-microvascular-proliferation+) phenotype of BRCA1-related breast cancer. Cancer Res. 2004 Feb 1;64(3):830-5.

28. Lindahl T, Landberg G, Ahlgren J, Nordgren H, Norberg T, Klaar S, Holmberg L, Bergh J. Overexpression of cyclin E protein is associated with specific mutation types in the p53 gene and poor survival in human breast cancer. Carcinogenesis. 2004 Mar;25(3):375-80.

29. Peters MG, Vidal Mdel C, Giménez L, Mauro L, Armanasco E, Cresta C, Bal de Kier Joffé E, Puricelli L. Prognostic value of cell cycle regulator molecules in surgically resected stage I and II breast cancer. Oncol Rep. 2004 Nov;12(5):1143-50.

30. Arnes JB, Brunet JS, Stefansson I, Bégin LR, Wong N, Chappuis PO, Akslen LA, Foulkes WD. Placental cadherin and the basal epithelial phenotype of BRCA1-related breast cancer. Clin Cancer Res. 2005 Jun 1;11(11):4003-11.

31. Chappuis PO, Donato E, Goffin JR, Wong N, Bégin LR, Kapusta LR, Brunet JS, Porter P, Foulkes WD. Cyclin E expression in breast cancer: predicting germline BRCA1 mutations, prognosis and response to treatment. Ann Oncol. 2005 May;16(5):735-42.

32. Callagy GM, Pharoah PD, Pinder SE, Hsu FD, Nielsen TO, Ragaz J, Ellis IO, Huntsman D, Caldas C. Bcl-2 is a prognostic marker in breast cancer independently of the Nottingham Prognostic Index. Clin Cancer Res. 2006 Apr 15;12(8):2468-75.

33. Desmedt C, Ouriaghli FE, Durbecq V, Soree A, Colozza MA, Azambuja E, Paesmans M, Larsimont D, Buyse M, Harris A, Piccart M, Martiat P, Sotiriou C. Impact of cyclins E, neutrophil elastase and proteinase 3 expression levels on clinical outcome in primary breast cancer patients. Int J Cancer. 2006 Dec 1;119(11):2539-45.

34. Sieuwerts AM, Look MP, Meijer-van Gelder ME, Timmermans M, Trapman AM, Garcia RR, Arnold M, Goedheer AJ, de Weerd V, Portengen H, Klijn JG, Foekens JA. Which cyclin E prevails as prognostic marker for breast cancer? Results from a retrospective study involving 635 lymph node-negative breast cancer patients. Clin Cancer Res. 2006 Jun 1;12(11 Pt 1):3319-28.

35. Somlo G, Chu P, Frankel P, Ye W, Groshen S, Doroshow JH, Danenberg K, Danenberg P. Molecular profiling including epidermal growth factor receptor and p21 expression in high-risk breast cancer patients as indicators of outcome. Ann Oncol. 2008 Nov;19(11):1853-9.

36. Potemski P, Kusińska R, Pasz-Walczak G, Piekarski JH, Watała C, Płuciennik E, Bednarek AK, Kordek R. Prognostic relevance of cyclin E expression in operable breast cancer. Med Sci Monit. 2009 Feb;15(2):MT34-40.

37. Sgambato A, Camerini A, Collecchi P, Graziani C, Bevilacqua G, Capodanno A, Migaldi M, Masciullo V, Scambia G, Rossi G, Cittadini A, Amoroso D. Cyclin E correlates with manganese superoxide dismutase expression and predicts survival in early breast cancer patients receiving adjuvant epirubicin-based chemotherapy. Cancer Sci. 2009 Jun;100(6):1026-33.

38. Lemée F, Bergoglio V, Fernandez-Vidal A, Machado-Silva A, Pillaire MJ, Bieth A, Gentil C, Baker L, Martin AL, Leduc C, Lam E, Magdeleine E, Filleron T, Oumouhou N, Kaina B, Seki M, Grimal F, Lacroix-Triki M, Thompson A, Roché H, Bourdon JC, Wood RD, Hoffmann JS, Cazaux C. DNA polymerase theta up-regulation is associated with poor survival in breast cancer, perturbs DNA replication, and promotes genetic instability. Proc Natl Acad Sci USA. 2010 Jul 27;107(30):13390-5.

39. Tokai Y, Maeda S, Yamaguchi J, Uga T, Hayashida N, Taniguchi K, Eguchi S, Kanematsu T. Cyclin E low-molecular-weight isoform as a predictor of breast cancer in Japanese women. Int Surg. 2011 Jul-Sep;96(3):245-53.

40. Voduc D, Nielsen TO, Cheang MC, Foulkes WD. The combination of high cyclin E and Skp2 expression in breast cancer is associated with a poor prognosis and the basal phenotype. Hum Pathol. 2008 Oct;39(10):1431-7.

41. Lundgren C, Ahlin C, Holmberg L, Amini RM, Fjällskog ML, Blomqvist C. Cyclin E1 is a strong prognostic marker for death from lymph node negative breast cancer. A population-based case-control study. Acta Oncol. 2015 Apr;54(4):538-44.

42. Johnston SJ, Syed BM, Parks RM, Monteiro CJ, Caruso JA, Green AR, Ellis IO, Hunt KK, Karakas C, Keyomarsi K, Cheung KL. Cytoplasmic Cyclin E Is an Independent Marker of Aggressive Tumor Biology and Breast Cancer-Specific Mortality in Women over 70 Years of Age. Cancers (Basel). 2020 Mar 18;12(3):712.

43. Stang A. Critical evaluation of the Newcastle-Ottawa scale for the assessment of the quality of nonrandomized studies in meta-analyses. Eur J Epidemiol. 2010 Sep;25(9):603-5.

44. Nielsen NH, Lodén M, Cajander J, Emdin SO, Landberg G. G1-S transition defects occur in most breast cancers and predict outcome. Breast Cancer Res Treat. 1999 Jul;56(2):105-12.

45. Potemski P, Pluciennik E, Bednarek AK, Kusinska R, Jesionek-Kupnicka D, Pasz-Walczak G, Watala C, Kordek R. Cyclin E expression in operable breast cancer quantified using real-time RT-PCR: a comparative study with immunostaining. Jpn J Clin Oncol. 2006 Mar;36(3):142-9.

46. Koff A, Cross F, Fisher A, Schumacher J, Leguellec K, Philippe M, Roberts JM. Human cyclin E, a new cyclin that interacts with two members of the CDC2 gene family. Cell. 1991 Sep 20;66(6):1217-28.

47. Lew DJ, Dulić V, Reed SI. Isolation of three novel human cyclins by rescue of G1 cyclin (CIn) function in yeast. Cell. 1991 Sep 20;66(6):1197-206. 
48. Cordon-Cardo C. Mutations of cell cycle regulators. Biological and clinical implications for human neoplasia. Am J Pathol. 1995 Sep;147(3):545-60.

49. Bortner DM, Rosenberg MP. Induction of mammary gland hyperplasia and carcinomas in transgenic mice expressing human cyclin E. Mol Cell Biol. 1997 Jan;17(1):453-9.

50. Sherr CJ. G1 phase progression: cycling on cue. Cell. 1994 Nov 18;79(4):551-5.

51. Ohtsubo M, Theodoras AM, Schumacher J, Roberts JM, Pagano M. Human cyclin E, a nuclear protein essential for the G1-to-S phase transition. Mol Cell Biol. 1995 May;15(5):2612-24.

52. Ohtsubo M, Roberts JM. Cyclin-dependent regulation of G1 in mammalian fibroblasts. Science. 1993 Mar 26;259(5103):1908-12.

53. Wimmel A, Lucibello FC, Sewing A, Adolph S, Müller R. Inducible acceleration of G1 progression through tetracycline-regulated expression of human cyclin E. Oncogene. 1994 Mar;9(3):995-7.

54. Möröy T, Geisen C. Cyclin E. Int J Biochem Cell Biol. 2004 Aug;36(8):1424-39.

55. Akama Y, Yasui W, Yokozaki H, Kuniyasu H, Kitahara K, Ishikawa T, Tahara E. Frequent amplification of the cyclin E gene in human gastric carcinomas. Jpn J Cancer Res. 1995 Jul;86(7):617-21.

56. Demetrick DJ, Matsumoto S, Hannon GJ, Okamoto K, Xiong Y, Zhang H, Beach DH. Chromosomal mapping of the genes for the human cell cycle proteins cyclin C (CCNC), cyclin E (CCNE), p21 (CDKN1) and KAP (CDKN3). Cytogenet Cell Genet. 1995;69(3-4):190-2.

57. Harwell RM, Porter DC, Danes C, Keyomarsi K. Processing of cyclin E differs between normal and tumor breast cells. Cancer Res. 2000 Jan $15 ; 60(2): 481-9$.

58. Keyomarsi K, Conte D Jr, Toyofuku W, Fox MP. Deregulation of cyclin E in breast cancer. Oncogene. 1995 Sep 7;11(5):941-50.

59. Wang XD, Rosales JL, Magliocco A, Gnanakumar R, Lee KY. Cyclin E in breast tumors is cleaved into its low molecular weight forms by calpain. Oncogene. 2003 Feb 6;22(5):769-74.

60. Wang L, Shao ZM. Cyclin e expression and prognosis in breast cancer patients: a meta-analysis of published studies. Cancer Invest. 2006 Oct;24(6):581-7.

61. Gao S, Ma JJ, Lu C. Prognostic value of cyclin E expression in breast cancer: a meta-analysis. Tumour Biol. 2013 Dec;34(6):3423-30.

62. Keyomarsi K, O'Leary N, Molnar G, Lees E, Fingert HJ, Pardee AB. Cyclin E, a potential prognostic marker for breast cancer. Cancer Res. 1994 Jan 15;54(2):380-5.

63. Porter DC, Zhang N, Danes C, McGahren MJ, Harwell RM, Faruki S, Keyomarsi K. Tumor-specific proteolytic processing of cyclin E generates hyperactive lower-molecular-weight forms. Mol Cell Biol. 2001 Sep;21(18):6254-69.

\section{Supplementary Information}

Additional file 1. Searching strategy

Additional file 2. Survival data indicator of original articles

Additional file 3. Quality assessment of the eligible studies

Additional file 4. Forest plots of the relationship between Cyclin E and clinicopathological features

\section{Figures}




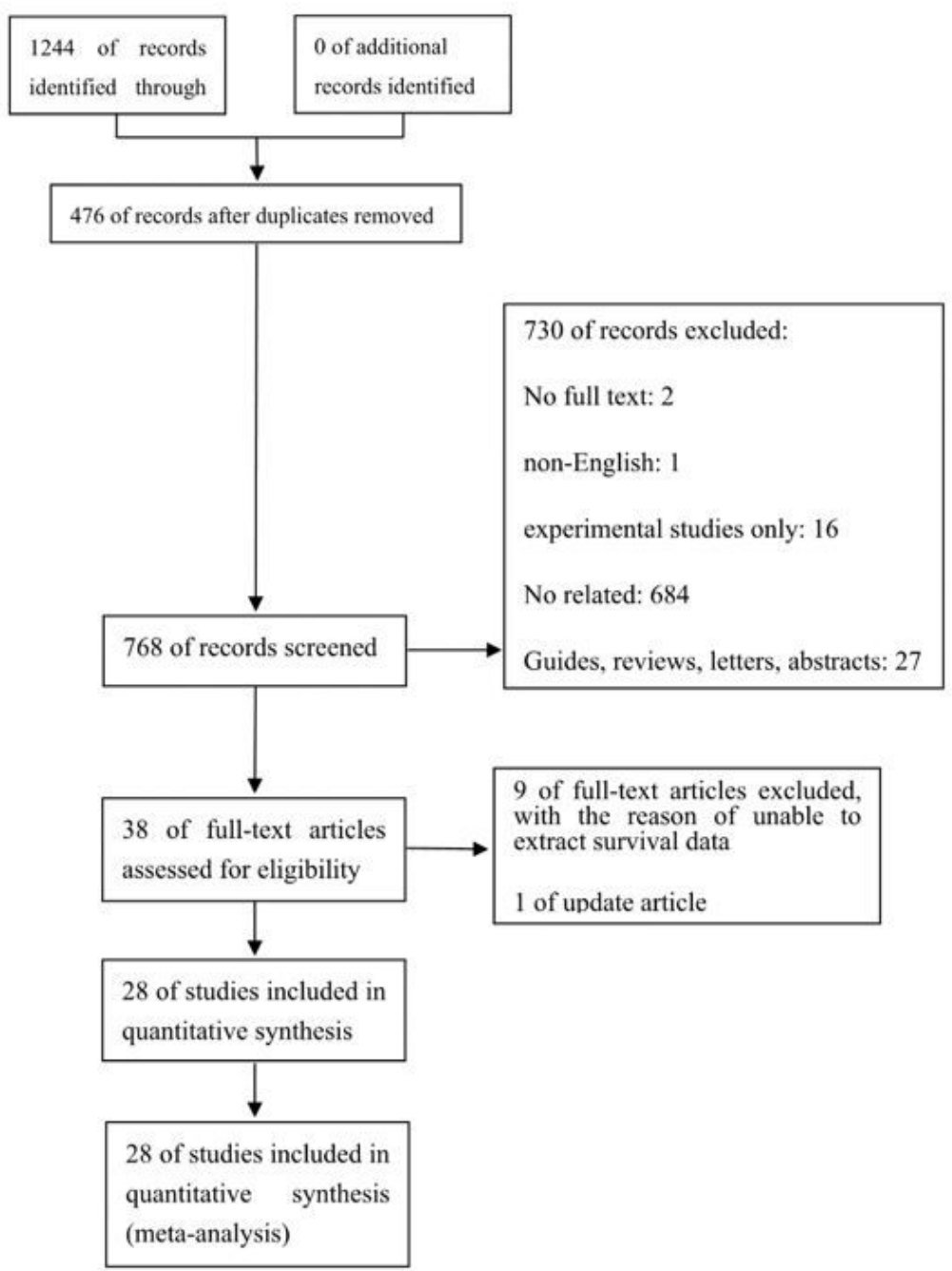

Figure 1

Literature screening flow chart 
A. HR for BCSS in univariate analysis

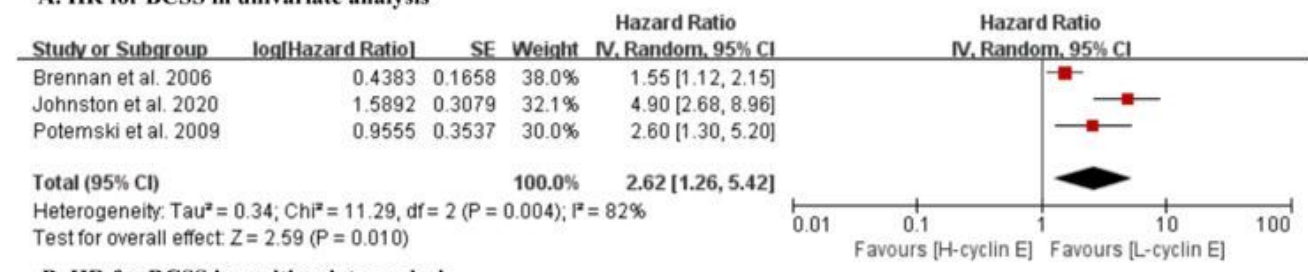

B. HR for BCSS in multivariate analysis

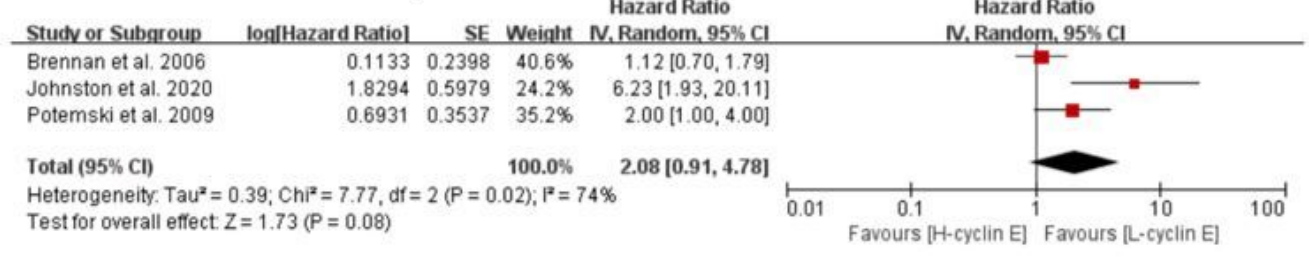

C. RR for BCSS in univariate analysis

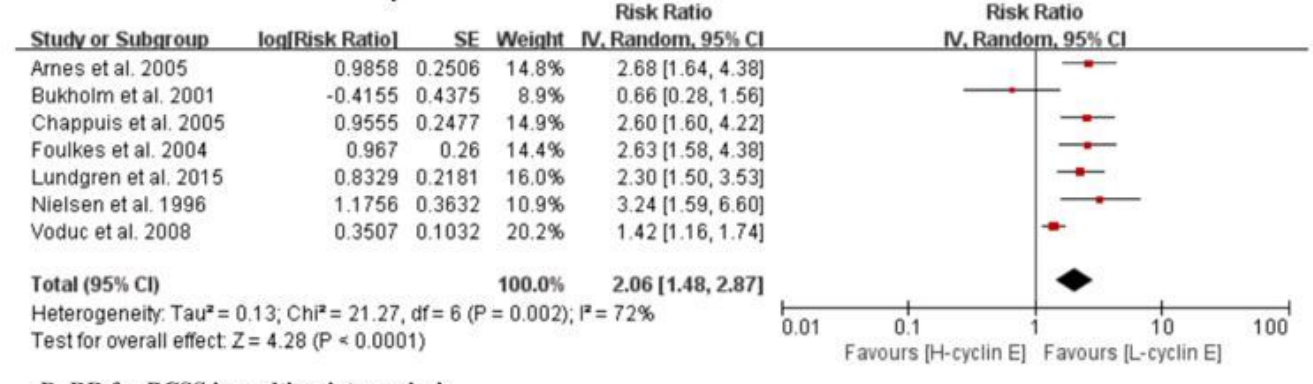

D. RR for BCSS in multivariate analysis

Risk Ratio

Risk Ratio

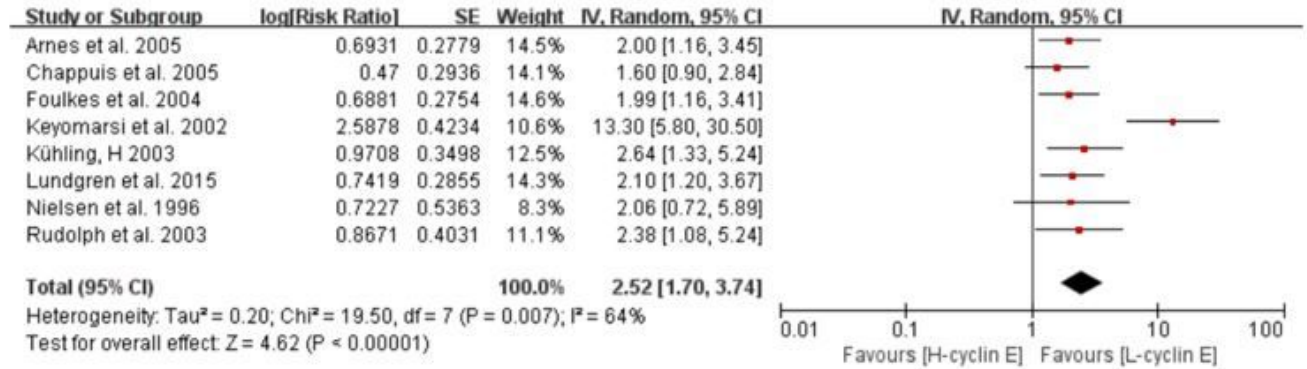

Figure 2

Estimated HRs and RRs summary for BCSS 
A. HR for $O S$ in univariate analysis

Hazard Ratio

Hazard Ratio

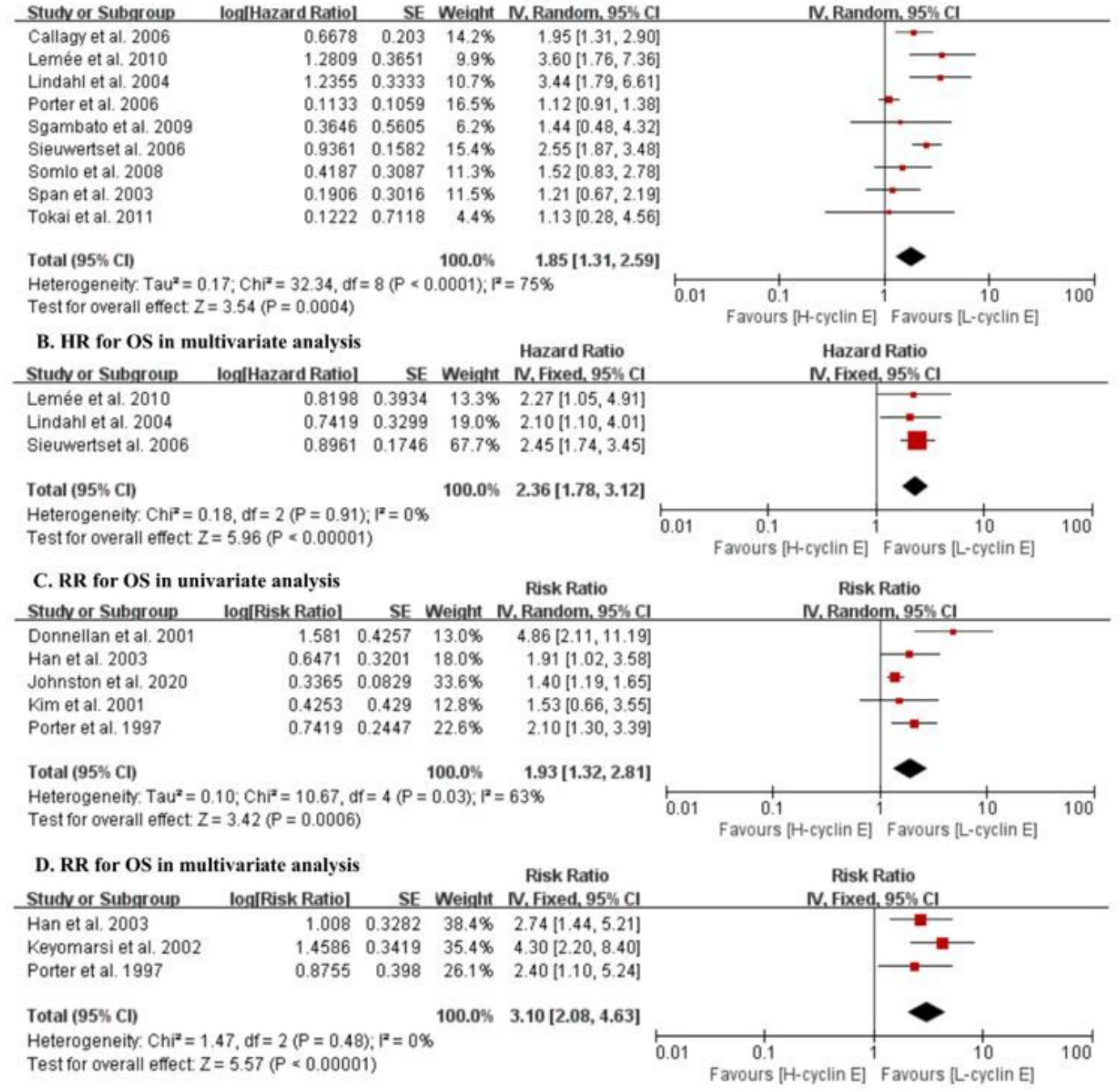

Figure 3

Estimated HRs and RRs summary for OS 
A. HR for RFS in univariate analysis

Hazard Ratio

Hazard Ratio

\begin{tabular}{|c|c|c|c|c|c|c|c|c|}
\hline Studv or Subgroup & log[Hazard Ratiol & \multicolumn{3}{|c|}{ SE Weight $\mathrm{N}$, Random, $95 \% \mathrm{Cl}$} & \multicolumn{4}{|c|}{ N. Random, $95 \% \mathrm{Cl}$} \\
\hline Desmedt et al. 2006 & 0.8154 & 0.2591 & $15.8 \%$ & $2.26[1.36,3.76]$ & & & 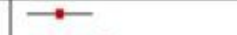 & \\
\hline Peters et al. 2004 & 1.5326 & 0.625 & $8.7 \%$ & $4.63[1.36,15.76]$ & & & & \\
\hline Porter et al. 2006 & 0.0862 & 0.0865 & $18.6 \%$ & $1.09[0.92,1.29]$ & & & & \\
\hline Sieuwertset al. 2006 & 1.3429 & 0.1841 & $17.3 \%$ & $3.83[2.67,5.49]$ & & & & \\
\hline Somlo et al. 2008 & 0.2151 & 0.2845 & $15.3 \%$ & $1.24[0.71,2.17]$ & & & & \\
\hline Span et al. 2003 & 0.2852 & 0.2468 & $16.1 \%$ & $1.33[0.82,2.16]$ & & & & \\
\hline Tokai et al. 2011 & 0.5128 & 0.6691 & $8.1 \%$ & $1.67[0.45,6.20]$ & & & & \\
\hline \multirow{2}{*}{\multicolumn{5}{|c|}{$\begin{array}{l}\text { Total }(95 \% \mathrm{Cl}) \\
\text { Heterogeneity. } \mathrm{Tau}^{2}=0.33 ; \mathrm{Chi}^{2}=45.54, \mathrm{df}=6(\mathrm{P}<0.00001) ; \mathrm{l}^{2}=87 \%\end{array}$}} & & & & \\
\hline & & & & & 0.01 & $\begin{array}{l}0.1 \\
\text { Favours [ } \mathrm{H} \text {-cyc }\end{array}$ & $\begin{array}{c}10 \\
\text { urs [L-cyclin E] }\end{array}$ & $100^{\prime}$ \\
\hline \multicolumn{4}{|c|}{ B. RR for RFS in univariate analysis } & & \multirow{2}{*}{\multicolumn{4}{|c|}{$\begin{array}{c}\text { Risk Ratio } \\
\text { N. Random, } 95 \% \mathrm{Cl}\end{array}$}} \\
\hline Studv or Subgroup & log[Risk Ratio] & \multicolumn{3}{|c|}{ SE Weight IV.Random, $95 \% \mathrm{Cl}$} & & & & \\
\hline Bukholm et al. 2001 & 0.1133 & 0.4014 & $23.8 \%$ & $1.12[0.51,2.46]$ & & & \multirow{4}{*}{$\rightarrow-$} & \\
\hline Johnston et al. 2020 (1) & 2.2127 & 0.2233 & $26.1 \%$ & $9.14[5.90,14.16]$ & & & & \\
\hline Kim et al. 2001 & 1.0332 & 0.374 & $24.2 \%$ & $2.81[1.35,5.85]$ & & & & \\
\hline Nielsen et al. 1996 & 0.3365 & 0.2369 & $26.0 \%$ & $1.40[0.88,2.23]$ & & & & \\
\hline \multirow{2}{*}{\multicolumn{5}{|c|}{$\begin{array}{l}\text { Total }(95 \% \mathrm{Cl}) \\
\text { Heterogeneity. } \text { Tau }^{2}=1.08 ; \mathrm{Chi}^{2}=41.20, \mathrm{df}=3(\mathrm{P}<0.00001) ;\left.\right|^{2}=93 \%\end{array}$}} & & & & \\
\hline & & & & & 0.01 & 0.1 & 10 & 100 \\
\hline \multicolumn{5}{|c|}{ Test for overall effect: $Z=1.74(P=0.08)$} & & Favours $[\mathrm{H}$-cyclin E] & ] & \\
\hline \multicolumn{4}{|c|}{ C. RR for RFS in multivarate analysis } & Risk Ratio & \multirow{2}{*}{\multicolumn{4}{|c|}{$\begin{array}{l}\text { Risk Ratio } \\
\text { N. Fixed, } 95 \% \mathrm{Cl}\end{array}$}} \\
\hline Study or Subgroup & log[Risk Ratio] & SE & Weight 1 & N. Fixed, 95\% Cl & & & & \\
\hline Kim et al. 2001 & $0.7178 \quad 0$ & 0.3924 & $32.7 \%$ & $2.05[0.95,4.42]$ & & & $=$ & \\
\hline Kühling, H 2003 & 0.86710 & 0.3368 & $44.4 \%$ & $2.38[1.23,4.61]$ & & & $\rightarrow-$ & \\
\hline Nielsen et al. 1996 & 0.28520 & 0.4694 & $22.9 \%$ & $1.33[0.53,3.34]$ & & & & \\
\hline Total $(95 \% \mathrm{Cl})$ & & & $100.0 \%$ & $1.98[1.28,3.08]$ & & & & \\
\hline \multicolumn{5}{|c|}{$\begin{array}{l}\text { Heterogeneity: } \mathrm{Ch}^{2}=1.02, \mathrm{df}=2(P=0.60) ; \mathrm{I}^{2}=0 \% \\
\text { Test for overall effect: } Z=3.05(P=0.002)\end{array}$} & 01 & 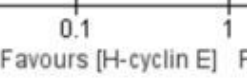 & $\begin{array}{c}10 \\
\text { Favours [L-cyclin E] }\end{array}$ & 100 \\
\hline
\end{tabular}

\section{Figure 4}

Estimated HRs and RRs summary for RFS 


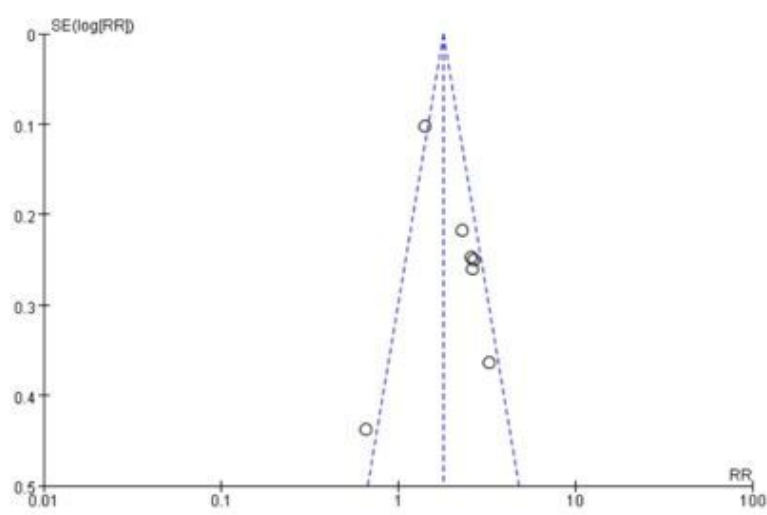

RR for BCSS in univariate analysis ( 7 studies)

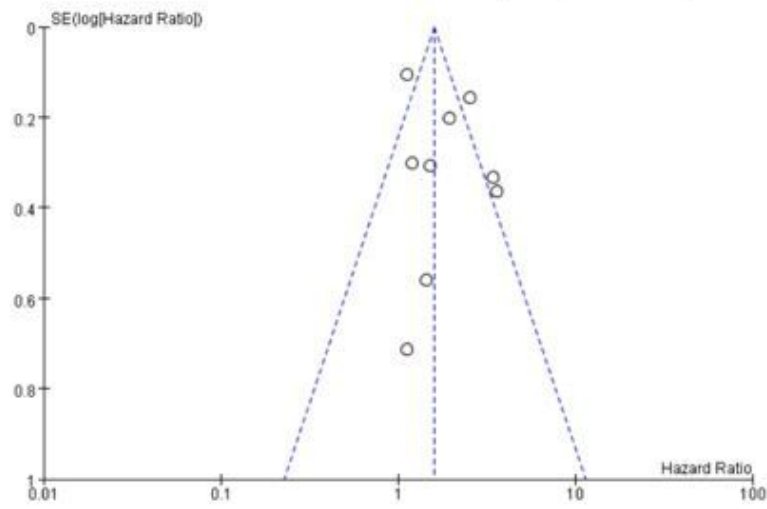

HR for OS in univariate analysis (9 studies)

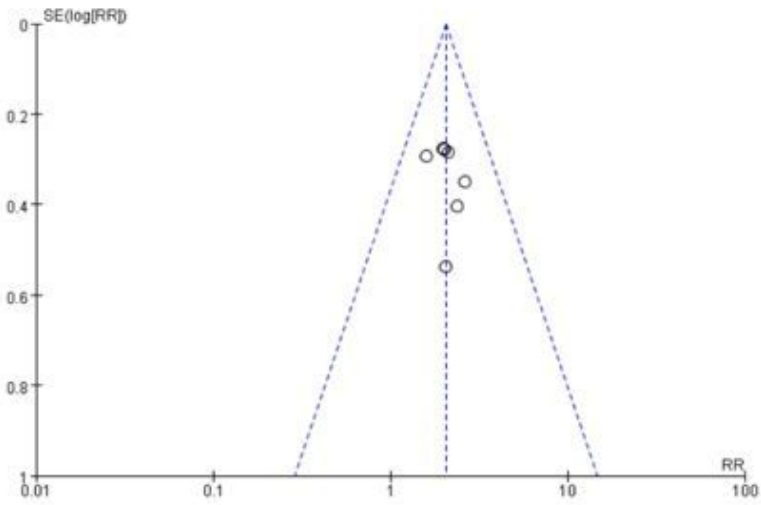

RR for BCSS in multivariate analysis (7 studies)

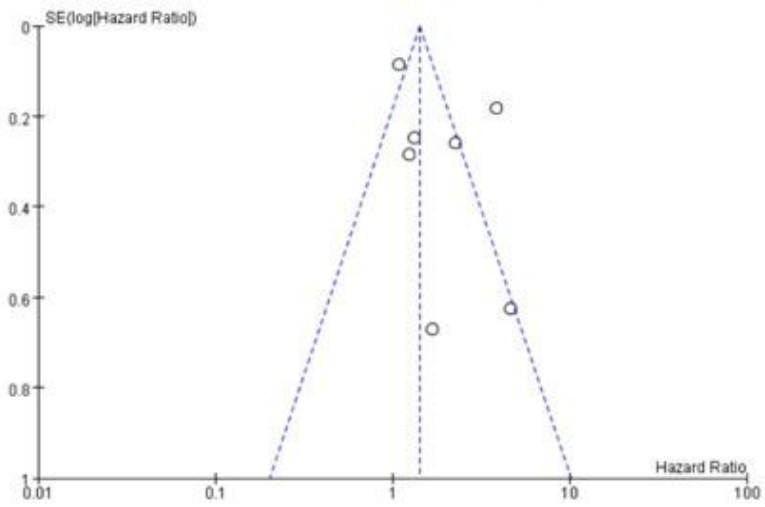

HR for RFS in univariate analysis ( 7 studies)

\section{Figure 5}

Funnel plots of studies

\section{Supplementary Files}

This is a list of supplementary files associated with this preprint. Click to download.

- Additionalfile1.Searchingstrategy.docx

- Additionalfile2.Survivaldataindicatoroforiginalarticles.docx

- Additionalfile3.Qualityassessmentoftheeligiblestudies..docx

- Additionalfile4.RelationshipbetweenCyclinEandclinicopathologicalfeatures.docx 